\title{
THE COMPARISON OF CELLULOLYTIC ACTIVITY OF THE MODIFIED SOIL TREATED WITH ROUNDUP
}

\author{
PORÓWNANIE AKTYWNOŚCI CELULOLITYCZNEJ \\ MODYFIKOWANEJ GLEBY POTRAKTOWANEJ ROUNDUPEM
}

\begin{abstract}
The activity of soil microorganisms affects soil fertility and structure, what leads to satisfactory crop yields, thanks to changes in the decay of organic matter. Their activity may be impaired as a result of application by farmers both fertilizers and pesticides. The degradation of cellulosic biomass represents an important part of the carbon cycle within the biosphere. Cellulolitic microorganisms are responsible for this decomposition, as they produced the enzymes of the cellulase complex. The aim of the study was to compare the cellulolytic activity of soil with Roundup and modified using urea phosphate and / or manure. The pot experiment was conducted under laboratory conditions. The studied material was brown soil $(\mathrm{pH}$ of 5.5) fertilized with manure and/or urea phosphate. To each earthenware vase were fed $0.5 \mathrm{~kg}$ of the tested soil supplemented with $1 \%$ carboxymethyl cellulose. The cellulolytic activities of soil in different experimental variants were expressed in \% of $\mathrm{C}$ using a colorimetric Petkov method. Modification of soil cellulolytic activity varied considerably depending on the additive manure and/or urea phosphate and Roundup. The lowest soil cellulolytic activity was observed in the presence of manure and urea phosphate, and the highest in the soil with manure and Roundup. The objects of Roundup independently of the other additives urea phosphate stimulate the activity of the cellulolytic microflora compared to objects containing only urea phosphate. The presence of manure in soil treated with Roundup clearly accelerated degradation of cellulose, what can be used in agriculture in the degradation of crop residues. The study shows that pesticides and fertilizers have a big impact on cellulolytic activity in soil. Changes in cellulolytic activity can be used as an ecological indicator of soil pollution level.
\end{abstract}

Keywords: cellulolytic activity of soil, Roundup

\section{Introduction}

The activity of soil microorganisms affects soil fertility and structure, which leads to satisfactory crop yields, thanks to changes in the decay of organic matter. Soil enzyme activities are the direct expression of the soil community to metabolic requirements and available nutrients. One of essential microbial function in soils is processing and recovery of key nutrients accumulated in soil organic matter. This often requires activity of extracellular enzymes to process complex organic compounds into assimilable subunits (sugars, amino acids, $\mathrm{NH}_{4}{ }^{+}, \mathrm{PO}_{4}{ }^{3-}$ ). The decomposition of organic matter is carried out by

\footnotetext{
${ }^{1}$ Department of Biotechnology and Molecular Biology, University of Opole, ul. kard. B. Kominka 6a, 45-035 Opole, Poland, phone +48 7740160 57, email: teresak@uni.opole.pl,mag18-89@o2.pl, mkoszal@o2.pl

*Corresponding author: teresak@uni.opole.pl
} 
enzymes like amylase, cellulase, invertase dehydrogenase and urease. Soil enzyme activities depend on physio-chemical parameters, microbial community structure, vegetation, additives like pesticide or fertilizers. However, no correlation was found between enzymatic activity and the amount of organic matter in soil or soil $\mathrm{pH}$.

The degradation of cellulosic biomass represents an important part of the carbon cycle within the biosphere. A large number of cellulolytic microorganisms are involved in the decomposition of plant material in soil but not much is known about their cellulolytic activity on quantitative basis. The changes of enzymatic activity belong to indicators which allow us to estimate changes in number of soil microorganisms and biodegradation ability of soil. This activity may be impaired as a result of the application by farmers both fertilizers and pesticides. Processing and mineralization of plant and animal residues occurring in soil have of great significance in agriculture. Plant cell walls consist a network of interwoven biopolymers that form crystalline structures. Cellulose, hemicellulose and lignin are the major structural components of woody plants and non-woody plants such as grass and represent a major source of renewable organic matter. The total amount of cellulose on Earth has been estimated at $700 \mathrm{Pg}\left(7 \cdot 10^{11} \mathrm{Mg}\right)$.

Cellulose is a polysaccharide with the formula $\left(\mathrm{C}_{6} \mathrm{H}_{5} \mathrm{O}_{10}\right)_{n}$, where $n$ ranges from 500 to 5000 , depending on the source of the polymer. It is composed of a linear chain of several hundred to over ten thousand $\beta(1 \rightarrow 4)$ linked D-glucose unit (Fig. 1). Cellulose chains linking together by hydrogen bonds and Van der Waals forces form fibrils. Thanks to a simple chain created by binding $\beta$-1,4-glycosidic bonds of the cellulose, the fibers have a high tensile strength. Cellulose mainly contains carbon $(44.44 \%)$, hydrogen $(6.17 \%)$, and oxygen $(49.39 \%)$ [1].

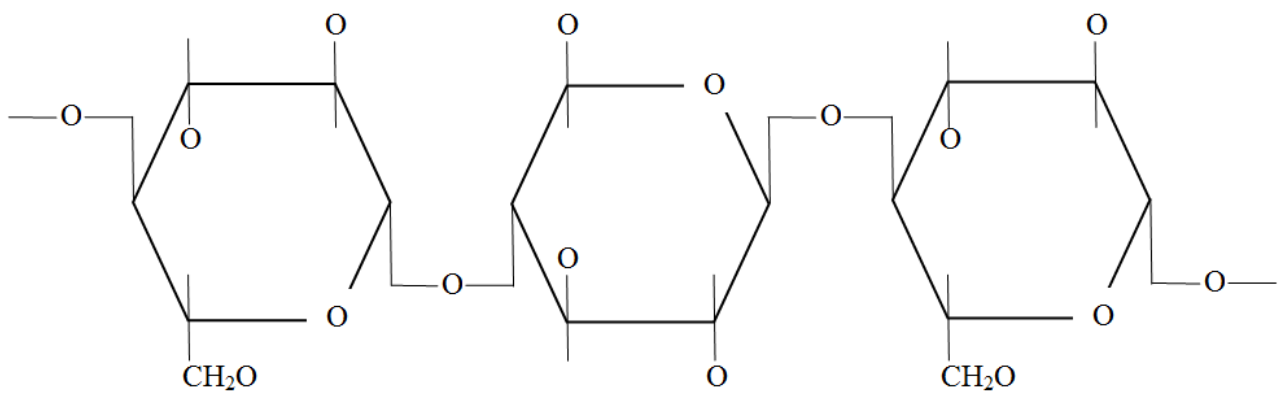

Fig. 1. Structure of cellulose

The decomposition leads to simple sugars that are used by the soil edaphon as the primary source of carbon in the environment. The ability to degrade cellulose have the microorganisms which produce cellulases enzyme complex. Cellulolitic enzymes, called cellulases, have been defined as the enzymes hydrolizing cellulose thereby yielding water and soluble sugar $[2,3]$.

Fungi are well known agents of the organic matter decomposition in general, and of the cellulosic substrate in particular [4]. There are many reports on fungi producing cellulases but only a few have proved high activities [5]. Under aerobic conditions, cellulose is degraded by the fungus types: Trichoderma, Penicillium, Aspergillus, Fusarium 
and Rhizopus [5-7]. The most active producer of cellulolytic enzymes was Aspergillus terreus and Aspergillus niger [8].

After the initial loosening of the material in further transformations are involved, among others, bacteria types: Cellulomonas, Streptomyce and Micromonospora [7, 9, 10]. There were also reported cellulolytic property of some bacterial genera such as, Cellvibrio, Pseudomonas, Micrococcus, Sporocytophaga and species as Bacillus cereus, Bacillus subtilis, Paenibacillus amylolyticus, Pseudomonas fluorescens and Serratia marcescens $[9,10]$.

The decomposition product is cellobiose, and even glucose, colorful compounds are often produced with uronic acids and proteins. Under anaerobic conditions, cellulose is degraded by bacteria of the genus Clostridium. However, in environments where oxygen access is difficult in the degradation of cellulose take part methanogenic archaea.

Cellulolytic microorganisms in soil provide carbon sources to improve the soil fertility and sustain the nutrient balance of the ecological system through the decomposition of cellulosic remains.

Cellulases are a group of enzymes that catalyze the cellulose degradation. This group consists of endo-1,4-glucanase (EC 3.2.1.4), exo-1,4-glucanase (EC 3.2.1.91), and $\beta$-d-glucosidase (EC 3.2.1.21). The products of cellulose degradation are glucose, cellobiose and oligosaccharides with higher molecular weight. Cellulose can be degraded to glucose with this enzyme in synergistic action [11-13].

The degree of cellulose decomposition is determined in the presence of different substrates (carboxymethylcellulose, Whatman filter paper No. 1, Avicel microcrystalline cellulose or cotton fiber ) by the following methods:

- colorimetric - by measuring the amount of reducing sugars calculated as glucose $[14,15]$,

- the electron microscopy - location of cellulase adsorption sites on a substrate, decomposition and structural changes in cellulose fibers [16-18],

- weighing method - to determine the total cellulolytic activity in soil,

- chemical method as measured by the intensity of the cellulolytic activity of the carbon dioxide evolution from soil enriched with cellulose [19, 20].

The aim of the study was to compare the cellulolytic activity in soil with Roundup and modified using urea phosphate and/or manure.

\section{Methods}

The pot experiment was conducted under laboratory conditions. The studied material was brown soil (S)( $\mathrm{pH}$ of 5.5), fertilized with manure (M) and/or urea phosphate (P) or treated with commonly used herbicide Roundup $(\mathrm{R})$. To each earthenware vase were fed $0.5 \mathrm{~kg}$ of the tested soil (S) supplemented with $1 \%$ carboxymethyl cellulose. Experiments pot was established in 4 replications in the following facilities: I-S, II-S + R, III-S + P, IV-S + P + R, V-S + M, VI-S + M + R, VII-S + M + P, VIII-S + M + M + R. Samples were incubated at $25^{\circ} \mathrm{C}$ for 90 days, maintaining a constant humidity level of $65 \%$ of the total water capacity. Cellulolytic activity was determined after 7, 30 and 90 days.

The cellulolytic activities of soil in different experimental variants were expressed in $\% \mathrm{C}$ using a colorimetric Petkov method [19]. 


\section{Results and discussion}

Cellulose is the main mass of organic matter, which is the totally or partially degraded by soil microorganisms. The biodegradation of cellulose has important consequences for the cultivation of arable soils, since under conditions of restricted oxygen supply metabolism microbial populations change significantly and as a result acetic acid accumulates in soil, reaching phytotoxic concentrations.

The degree of cellulose use as a major carbon source by soil microorganisms depends on abiotic factors, such as fertilization, pesticide use, $\mathrm{pH}$ and soil moisture and temperature. Long-term presence and accumulation of pesticides in soil is often the cause of modifications in microbiological soil activity. Most often these substances induce changes in quantities of soil microflora and enzymatic activity. The enzymatic activity belongs to indicators which allow us estimation of changes in polluted soil and soil biodegradation ability [20-22].

Our study included effects of fertilization with manure and / or use of Roundup on the degree of cellulose degradation by soil microorganisms in situ. The measure of cellulolytic activity in the test objects was carbon residue [\%] of the not decomposed therein carboxymethylcellulose (Table 1).

Table 1

The carbon content of the examined objects

\begin{tabular}{|c|c|c|c|c|c|c|}
\hline \multirow{2}{*}{ Object } & \multicolumn{2}{|c|}{ 7 days } & \multicolumn{2}{c|}{ 30 days } & \multicolumn{2}{c|}{ 90 days } \\
\cline { 2 - 7 } & $\mathbf{A}_{\mathbf{5 9 0}}$ & $\begin{array}{c}\text { Carbon } \\
\text { content [\%] }\end{array}$ & $\mathbf{A}_{\mathbf{5 9 0}}$ & $\begin{array}{c}\text { Carbon } \\
\text { content [\%] }\end{array}$ & $\mathbf{A}_{\mathbf{5 9 0}}$ & $\begin{array}{c}\text { Carbon } \\
\text { content [\%] }\end{array}$ \\
\hline $\mathrm{S}$ & 0.115 & 0.764 & 0.175 & 1.302 & 0.160 & 1.168 \\
\hline $\mathrm{S}+\mathrm{M}$ & 0.170 & 1.258 & 0.185 & 1.392 & 0.185 & 1.392 \\
\hline $\mathrm{S}+\mathrm{P}$ & 0.180 & 1.347 & 0.210 & 1.617 & 0.175 & 1.302 \\
\hline $\mathrm{S}+\mathrm{R}$ & 0.200 & 1.527 & 0.180 & 1.347 & 0.205 & 1.572 \\
\hline $\mathrm{S}+\mathrm{M}+\mathrm{P}$ & 0.200 & 1.527 & 0.235 & 1.841 & 0.185 & 1.392 \\
\hline $\mathrm{S}+\mathrm{M}+\mathrm{R}$ & 0.170 & 1.258 & 0.195 & 1.242 & 0.175 & 1.200 \\
\hline $\mathrm{S}+\mathrm{M}+\mathrm{R}+\mathrm{P}$ & 0.185 & 1.392 & 0.195 & 1.482 & 0.210 & 1.617 \\
\hline $\mathrm{S}+\mathrm{R}+\mathrm{P}$ & 0.170 & 1.258 & 0.170 & 1.258 & 0.180 & 1.347 \\
\hline
\end{tabular}

Cellulolytic activity, expressed as a loss of carbon in $\mathrm{CO}_{2}$ in the test objects with the addition of carboxymethylcellulose, were determined in relation to the seventh day of the experiment (Table 2).

Table 2

The carbon content as the indicator of cellulolytic activity of soil in relation to the seventh day of the experiment

\begin{tabular}{|c|c|c|}
\hline \multirow{2}{*}{ Object } & 30 days & 90 days \\
\cline { 2 - 3 } & Carbon content [\%] & Carbon content [\%] \\
\hline $\mathrm{S}$ & 0.135 & 0.808 \\
\hline $\mathrm{S}+\mathrm{M}$ & 0.584 & 0.584 \\
\hline $\mathrm{S}+\mathrm{P}$ & 0.540 & 0.314 \\
\hline $\mathrm{S}+\mathrm{R}$ & 0.539 & 0.629 \\
\hline $\mathrm{S}+\mathrm{M}+\mathrm{P}$ & 0.719 & 0.719 \\
\hline $\mathrm{S}+\mathrm{M}+\mathrm{R}$ & 0.016 & 0.058 \\
\hline $\mathrm{S}+\mathrm{M}+\mathrm{R}+\mathrm{P}$ & 0.225 & 0.404 \\
\hline $\mathrm{S}+\mathrm{R}+\mathrm{P}$ & 0.404 & 0.135 \\
\hline
\end{tabular}


Cellulolytic activity index of the soil is inversely proportional to the evolved and determined $\mathrm{CO}_{2}$. The higher content of $\mathrm{CO}_{2}$ in the test samples indicate a lower degree of carboxymethyl cellulose decomposition in the soil, and thus - for limited cellulolytic activity of autochthonous soil microflora.

Introduction to soil different groups of pesticides in the field dose and 10 times higher resulted in generally increase in cellulolytic activity. In contrast, a 100-fold higher than the field dose of these pesticides have led to the inhibition of the cellulolytic activity [23].

Cellulase yields appear to depend on a complex relationship involving a variety of factors like inoculum size, $\mathrm{pH}$ value, temperature, presence of inducers, medium additives, aeration, growth time, and so forth [10, 24, 25].

Sethi et al. [10] observed the high activity and stability of cellulose enzymes between neutral to alkaline $\mathrm{pH}$ and high temperature. Also, production of extracellular cellulases and sensitivity to repression of different carbohydrate and nitrogen sources has been shown. Nitrogen is one of the major stimulator of cellulolytic activity. Among the various nitrogen sources, ammonium sulphate was found to be the best nitrogen source for production of cellulases [10]. In our study presence of manure in soil treated with Roundup clearly accelerated degradation of cellulose, what can be used in agriculture in the decomposition of crop residues.

The study shows that pesticides and fertilizers have a big impact on cellulolytic activity in soil. Changes in cellulolytic activity can be used as an ecological indicator of level of soil pollution.

\section{Conclusions}

1. The soil cellulolytic activities varied significantly depending on the addition of manure and / or urea phosphate and Roundup.

2. The lowest soil cellulolytic activity was observed in the presence of manure and urea phosphate, and the highest in the soil with manure and Roundup.

3. The presence of manure in soil treated with Roundup clearly enhanced the degradation of cellulose, which can be used in agriculture in the decomposition of crop residues.

\section{References}

[1] Spence KL, Venditti RA, Habibi Y, Rojas OJ, Pawlak JJ. The effect of chemical composition on microfibrillar cellulose films from wood pulps: mechanical processing and physical properties. Bioresour Technol. 2010;101:5961-5968. DOI: 10.1016/j.biortech.2010.02.104.

[2] Rapa P, Beermann A. Bacterial cellulase. In: Biosyntesis and Biodegradation of Cellulose. Haigler CH, Weimer PJ, editors. New York: Marcel Dekker; 1991;535-599.

[3] Russel S, Górska EB, Wyczółkowski AI. Enzymy biorące udział w hydrolizie celulozy. [Enzymes taking part in hydrolysis of cellulose]. Acta Agrophysica, Rozpr Monografie. 2005;3:27-36. http://www.old.acta-agrophysica.org/en/monograph.html?stan=detail\&paper=518.

[4] Lynd LR, Weimer PJ, van Zyl WH, Pretorius IS. Microbial cellulose utilization: fundamentals and biotechnology. Microbiol Mol Biol Rev. 2002;66:506-577. DOI: 10.1128/MMBR.66.3.506-577.2002.

[5] Vries RP, Visser J. Aspergillus enzymes involved in degradation of plant cell wall polysaccharide. Microbiol Mol Biol Rev. 2001;65(4):497-522. DOI: 10.1128/MMBR.65.4.497-522.2001.

[6] Narasimha G, Sridevi A, Buddolla V, Subhosh CM, Rajasekar RB. Nutrient effects on production of cellulolytic enzymes by Aspergillus niger. Afr J Biotechnol. 2006;5(5):472-476. DOI: 10.5897/AJB05.224.

[7] Sri Lakshmi A, Narasimha G. Production of cellulases by fungal cultures isolated from forest litter soil. Ann For Res. 2012;55(1):85-92. http://www.editurasilvica.ro/afr/55/1/narasimha.pdf. 
[8] Mirzaakhmedov SY, Ziyavitdinov ZF, Akhmedova ZR, Saliev AB, Ruzmetova DT, Ashurov KB, et al. Isolation, purification and enzymatic activity of cellulase components the fungus Aspergillus terreus. Chem Nat Compd. 2007;43(5):594-597. DOI: 10.1007/s10600-007-0199-6.

[9] Immanuel G, Dhanusha R, Prema P, Palavesam A. Effect of different growth parameters on endoglucanase enzyme activity by bacteria isolated from coir retting effluents of estuarine environment. Int J Environ Sci Technol. 2006;3(1):25-34. DOI: 10.1007/BF03325904.

[10] Sethi S, Datta A, Gupta BL, Gupta S. Optimization of cellulase production from bacteria isolated from soil. Int Scholarly Res Notices. Biotechnol. 2013; Article ID 985685. DOI: 10.5402/2013/985685.

[11] Deng SP, Tabatabai MA. Cellulase activity of soils. Soil Biol Biochem. 1994;26(10):1347-1354. DOI: 10.1016/0038-0717(94)90216-X.

[12] Matsui I, Sakai Y, Matsui E, Kikuchi E, Kawarabayasi Y, Honda K. Novel substrate specificity of a membrane-bound beta-glycosidase from the hyperthermophilic archaeon Pyrococcus horikoshii. Fed Europ Biochem Soc Lett. 2000;467:195-200. DOI: 10.1016/S0014-5793(00)01156-X.

[13] Bhat MK. Cellulases and related enzymes in biotechnology. Biotechnol Advanc. 2000;18(5):355-383.

[14] Updegraff DM. Semimicro determination of cellulose in biological materials. Anal Biochem. 1969;32(3):420-424. DOI: 10.1016/S0003-2697(69)80009-6.

[15] Updegraff DM. Utilization of cellulose from waste paper by Myrothecium verrucaria. Biotechnol Bioeng. 1971;13(1):77-97. DOI: 10.1002/bit.260130106.

[16] Chanzy H, Hennrissat B, Vuong R. Colloidal gold labeling of 1,4- $\beta$-D-glucan cellobiohydrolase adsorbed on cellulose substrates. Fed Europ Biochem Soc Lett. 1984;172(2):193-197. DOI: 10.1016/0014-5793(84)81124-2.

[17] Chanzy H, Henrissat B. Unidirectional degradation of valonia cellulose microcrystals subjected to cellulase action. Fed Europ Biochem Soc Lett. 1985;184:285-288. DOI: 10.1016/0014-5793(85)80623-2.

[18] Sprey B, Bochem H.P. Electron microscopic observations of cellulose microfibrill degradation by endocellulase from Trichoderma reesei. Fed Europ Microbiol Soc Microbiol Lett. 1991;78:183-188. DOI: 10.1111/j.1574-6968.1991.tb04440.x

[19] Petkov PD, Markova TCh. A method of studying cellulose decomposition in soil. Biologie du Sol. 1969;10:17. www.iung.pulawy.pl

[20] Frankenberger WT, Johanson JB. Method of measuring invertase activity in soils. Plant Soil. 1983;74:301-311. DOI: 10.1007/BF02181348.

[21] Baćmaga M, Kucharski J, Wyszkowska J. Wpływ środków ochrony roślin na aktywność mikrobiologiczną gleb. [Influence of plant protection products on the microbiological activity of soil]. J Elem. 2007;12(3):225-239. http://www.uwm.edu.pl/jelementol.

[22] Krzyśko-Łupicka T, Grata K. Influence of Roundup on the chosen biological and chemical properties of soil. In: Chemistry for Agriculture. Chemicals in agriculture and environment. Górecki H, Dobrzański Z, Kafarski P, Zwoździak J, editors. Prague-Brussels: Wyd. Czech-Pol Trade; 2007;8:151-157. www.bch.pwr.wroc.pl.

[23] Michalewicz W. Wpływ pestycydów stosowanych w chemicznej ochronie roślin uprawnych na niektóre właściwości biologiczne gleby [Influence of pesticides used in chemical protection of field crops on some biological properties of soil]. Roczn Gleboznaw. 1995;XLVI(1/2):53-64. http://www.degruyter.com/view/j/ssa.

[24] Rose HT, Cavagnaro TR, Scanlant CA, Rose TJ, Vancov T, Kimber S, et al. Impact of herbicides on soil biology and function. Advanc Agronom. 2016;136:133-220. DOI: 10.1016/bs.agron.2015.11.005.

[25] Yang JK, Zhang JJ, Yu HY, Cheng JW, Miao LH. Community composition and cellulase activity of cellulolytic bacteria from forest soils planted with broad-leaved deciduous and evergreen trees. Appl Microbiol Biotechnol. 2014;98(3):1449-58. DOI: 10.1007/s00253-013-5130-4.

\title{
PORÓWNANIE AKTYWNOŚCI CELULOLITYCZNEJ MODYFIKOWANEJ GLEBY POTRAKTOWANEJ ROUNDUPEM
}

\author{
Samodzielna Katedra Biotechnologii i Biologii Molekularnej, Uniwersytet Opolski, Opole
}

\begin{abstract}
Abstrakt: Aktywność mikroorganizmów gleby wpływa na jej żyzność oraz strukturę, co pozwala uzyskać satysfakcjonujące plony, między innymi dzięki przemianom materii organicznej w próchnicę. Proces ten zachodzi w obecności różnych grup mikroorganizmów, których aktywność może być zaburzona w wyniku stosowania przez rolników zarówno nawozów sztucznych, jak i organicznych oraz pestycydów. Ważnym ogniwem w obiegu węgla w biosferze jest degradacja celulozy. Rozkład celulozy zachodzi przy udziale drobnoustrojów o aktywności
\end{abstract}


celulolitycznej, które produkują enzymy kompleksu celulaz. Celem pracy było porównanie aktywności celulolitycznej gleby wzbogaconej fosforanem mocznika i/lub obornikiem po opryskaniu powszechnie stosowanym herbicydem Roundup. Doświadczenie wazonowe prowadzono w warunkach laboratoryjnych. Do badań użyto gleby brunatnej właściwej o pH 5,5, nawożonej obornikiem i/lub fosforanem mocznika, opryskanej Roundupem. Do każdego wazonu wprowadzano $0,5 \mathrm{~kg}$ badanej gleby wzbogaconej $1 \%$ karboksymetylocelulozy. Aktywność enzymów celulolitycznych w poszczególnych wariantach doświadczenia wyrażono w \% C, wydzielonego z gleby w postaci $\mathrm{CO}_{2}$, stosując kolorymetryczną metodę Petkova. Modyfikacja gleby znacząco zmieniała aktywność celulolityczną w zależności od dodatku obornika i/lub fosforanu mocznika oraz Roundupu. Najniższą aktywność celulolityczną gleby zaobserwowano w obecności obornika i fosforanu mocznika, a najwyższą w glebie z obornikiem i Roundupem. W obiektach z Roundupem niezależnie od innych dodatków fosforan mocznika stymulował aktywność mikroflory celulolitycznej, w porównaniu do obiektów zawierających tylko fosforan mocznika. Obecność obornika w glebie opryskanej Roundupem wyraźnie przyspieszała rozkład celulozy, co można wykorzystać w rolnictwie w rozkładzie resztek pożniwnych. Badania wykazały, że pestycydy i nawozy mają duży wpływ na celulolityczną aktywność gleby. Zmiany aktywności celulolitycznej gleby można wykorzystać jako ekologiczny wskaźnik jej jakości.

Słowa kluczowe: aktywność celulolityczna gleb, Roundup 